\title{
Author response
}

\author{
Sangeeta Pathak ${ }^{1}$ (D) $\cdot$ Mei Koh ${ }^{1} \cdot$ Ashish Pradhan $^{1}$
}

Received: 24 December 2020 / Accepted: 31 January 2021 / Published online: 8 March 2021

(C) The International Urogynecological Association 2021

\section{Dear Sir}

We thank the authors for their interest in our paper.

The crucial importance of the $60^{\circ}$ mediolateral episiotomy cutting angle has been investigated based on the research of Andrews [1], Eogan [2], Kalis [3, 4] and Stedenfeldt [5]. This angle is now recommended by the Royal College of Obstetricians and Gynaecologists Green-Top Guidelines nos. 26 and 29 [6]. The same is also endorsed by the Canadian SOGC, the French CNOG and the Saudi O\&G Society, amongst others.

Our results in sustained reduction of obstetric anal sphincter injuries (OASIS) with universal adoption of the EPISCISSORS-60 reflect those reported by others [7].

We have already shown that the EPISCISSORS-60 reduces OASIS in operative vaginal deliveries in the article. We agree that comparing characteristics mentioned such as ethnicity, age, maternal and foetal characteristics would have provided more insightful analysis. However, robust data for these characteristics were not available for the 2014 period.

Finally, we do not believe a randomized trial comparing the EPISCISSORS-60 (which simply ensure a fixed $60^{\circ}$ cutting episiotomy angle) to standard episiotomy scissors would be ethical. There are no data showing that clinicians can consistently eyeball a $60^{\circ}$ cut. Indeed, there is evidence to the contrary $[8]$.

\section{References}

1. Andrews V, Thakar R, Sultan AH, Jones PW. Are mediolateral episiotomies actually mediolateral? BJOG. 2005;112:1156-8.

2. Eogan M, Daly L, O'Connell PR, O'Herlihy C. Does the angle of episiotomy affect the incidence of anal sphincter injury? BJOG. 2006;113:190-4.

3. Kalis V, Karbanova J, Horak M, Lobovsky L, Kralickova M, Rokyta $Z$. The incision angle of mediolateral episiotomy before delivery and after repair. Int J Gynecol Obstet. 2008;103:5-8.

4. Kalis V, Landsmanova J, Bednarova B, Karbanova J, Laine K, Rokyta Z. Evaluation of the incision angle of mediolateral episiotomy at 60 degrees. Int J Gynecol Obstet. 2011;112:220-4.

5. Stedenfeldt M, Pirhonen J, Blix E, Wilsqaard T, Vonen B, Qian P. Episiotomy characteristics and risks for obstetric anal sphincter injury: a case-control study. BJOG. 2012;119:724-30.

6. RCOG. 2015. Greentop guideline 29: The Management of Thirdand Fourth-Degree Perineal tears. Available at: https://www.rcog. org.uk/globalassets/documents/guidelines/gtg-29.pdf

7. Mohiudin H, Ali S, Pisal PN, Villar R. Implementation of the RCOG guidelines for prevention of obstetric anal sphincter injuries (OASIS) at two London hospitals: a time series analysis. Eur J Obstet Gynecol Reprod Biol. 2018;224:89-92.

8. Naidu M, Kapoor DS, Evans S, Vinayakarao L, Thakar R, Sultan AH. Cutting an episiotomy at 60 degrees: how good are we? Int Urogynecol J. 2015;26(6):813-6.

Publisher's note Springer Nature remains neutral with regard to jurisdictional claims in published maps and institutional affiliations.

Sangeeta Pathak

sangeetapathak@nhs.net

1 Hinchingbrooke Hospital, Huntingdon, UK 